\title{
SUITABILITY OF TEXTURAL PARAMETERS FOR CHARACTERIZATION OF TRAPPIST CHEESE RIPENING
}

\author{
O. BARA-HERCZEGH ${ }^{\mathrm{a}}$, K. HORVÁTH-ALMÁSSYa ${ }^{\mathrm{a}}$ J. FENYVESSY ${ }^{\mathrm{a}}$ and F. ÖRSI ${ }^{\mathrm{b}}$

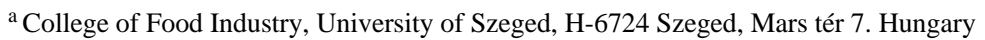 \\ ${ }^{\mathrm{b}}$ Department of Biochemistry and Food Technology, Technical University of Budapest, \\ H-1111 Budapest, Mûegyetem rkp. 3. Hungary
}

(Received: 13 January 2000; revision received: 6 October 2000; accepted: 14 November 2000)

The objectives of this study were to monitor the changes in textural parameters of Trappist cheese during ripening and shelf-life, and to find correlation between the changes in instrumental texture parameters and the age or sensory properties of the product. The textural parameters of Trappist samples of 5 different manufacturing processes were determined with a QTS 25 Texture Profile Analyser. In addition to the mechanical tests, composition analyses and sensory tests were also conducted. The empirical values from the mechanical tests were evaluated with statistical methods (single-valued and multivariate analysis). The age and the quality of the product can be estimated from the textural parameters despite the inhomogeneity of the samples that is due to the manufacturing processes.

Keywords: Trappist cheese, ripening, instrumental texture parameters, Texture Profile Analyser

Most rennet cheeses are ripened before consumption to achieve the desirable organoleptic qualities. Ripening involves a series of complex biochemical processes, which can be grouped broadly into proteolysis, lipolysis and lactose/lactate metabolism. The extent and type of ripening depend on storage time and temperature, cheese composition (especially moisture and salt levels) and the types and activities of enzymes and micro-organisms present. The physical and chemical changes that occur during ripening determine the overall organoleptic qualities of cheese (FARKYE \& FOX, 1990). The body of a cheese is closely related to its microstructure which may be regarded as gel-like and is modified by proteolysis and other biochemical changes during ripening (FOX \& MULVIHILL, 1990). The structure development in cheese is of particular interest because the development of structure takes place quite slowly and this can be followed by the accompanying changes in the rheological properties. Cheese is viscoelastic in nature, meaning that it exhibits both solid (elastic) and fluid (viscous) behaviour (KONSTANCE \& HOLSINGER, 1992). 
It would be advantageous to apply easily applicable, rapid physical methods which are suitable for routine work for the characterisation of the consistency and texture of cheese based on well-defined textural parameters.

The aim of this study was to find correlation between measured textural or mechanical parameters and the age of Trappist cheese in order to be able to trace and determine cheese ripening. We supposed that the textural parameters measured accurately under well-defined conditions might provide supplementary information for cheese grading.

Trappist is the most popular cheese in Hungary. It is of French origin, an invention of the friars of the "Notre Dame de Port du Salut" monastery. It appeared in our country at the end of the 19th century. It is a salted, ripened semi-hard cheese with characteristic sensory properties, which is made from pasteurized cow's milk and added lactic acid forming starter cultures (Streptococcus lactis, Streptococcus cremoris, Leuconostoc citrovorum, Leuconostoc dextranicus, Streptococcus diacetillactis), rennin, calcium chloride, and potassium nitrate. The weight of the product is about $1-1.5 \mathrm{~kg}$, the form is disc-shaped and it is packed in a plastic foil that is shrinking for heat treatment. Its cutting surface is consistently pale yellow, dry or slightly wet to the feel. Some shiny round holes can be seen, whose diameter is 3-4 mm. Trappist cheese can be sliced well, easy to shape, elastic and it crumbles in the mouth. Its taste and smell are characteristically aromatic, mellow, acidulous, slightly salty (KLIERMEIER \& LECHNER, 1973, CODEX ALIMENTARIUS HUNGARICUS, 1995).

Viscoelasticity may be demonstrated with rheological multicomponent models. These models consist of elastic springs obeying Hooke's law, and viscous dashpots which obey the Newtonian law of viscosity. The simplest possible models consist of a single spring and dashpot in series (Maxwell model) or in parallel (Voight or Kelvin model) connection. In the Kelvin body the deformation and the recovery are not instantaneous. This is in line with practical experience. The detailed investigation of the Maxwell and Kelvin models shows that exactly these ones do not demonstrate the viscoelastic form-change, though the Kelvin model gives the better approximation. With the extension of the Voigt and Maxwell bodies, the Burgers body is produced in a way that a Voigt body is placed end-to-end with a Maxwell body. In this model both the deformation and recovery are retarded to various degrees and the recovery is incomplete (PRENTICE, 1984a). As the number of elements increases it becomes disproportionately difficult to analyse the data. Only the simplest models have practical importance.

The rheological properties of cheese depend upon its structure. The three major constituents of cheese are casein, fat, and water, each contribute to the structure and therefore to the rheological properties in its own specific way. At room temperature, the casein is solid, the fat is a mixture of solid and liquid fractions, giving it what may be described as plastic properties, and the free water is liquid. Casein forms and open 
mesh-like structure (CREAMER \& OLSON, 1982). Fat is entrapped in this mesh. The aqueous phase contains the soluble constituents of the milk serum and some salt that was added during cheese making. Some of the water is bound to protein so it is largely immobilised. The remainder is free and fills the interstices between the casein matrix and fat.

The primary structure of the cheese curd is a three-dimensional grid whose sides consist of chains of casein molecules. This provides a structure of considerable inherent rigidity. During the clotting process these chains join together the individual casein particles in the serum. The serum surrounds the fat globules so that each cage encases at least one globule or cluster of globules. The complete cheese curd after the clotting process consists of an aggregate of these cells of casein plus fat and the whole is pervaded by the aqueous phase. If a force is applied to this structure, the deformation will be primarily controlled by the rigidity of the grid, modified by any elasticity in its structural members. The fat within it limits the deformation of the cells. At very low temperatures the fat would be solid and this would only add to the rigidity. At normal temperature, at which cheese is ripened and consumed, the fat has both solid and liquid constituents and has its own peculiar rheological properties. Any deformation of the casein matrix would also require the fat to deform. The water between the fat and the casein acts as a lubricant. As a result, the rigidity of the fat is added to that of the casein in a complex manner and it is this, which gives rise to the peculiar viscoelastic properties of the cheese.

The end product is not a continuous aggregate of cells. During manufacturing, the curd is cut into small pieces at least once to allow any excess serum to drain away. As the serum drains away, the casein matrix shrinks onto the fat globules, making a more compact whole. The final cheese mass is an aggregation of these granules which forms a secondary structure having its own set of rheological properties. Some processes such as pressing distort the whole structure of the cheese. During manufacturing and the subsequent ripening, the basic structure may be modified by mechanical or thermal treatment, or bacteria and any residual enzymes may act upon the casein. These agents may change the organisation of the structure or they may cause continuous fat globules to coalesce. Finally, water may be lost by evaporation from the surface (PRENTICE, 1984b). During maturation, primarily its $\mathrm{pH}$ and the ratio of casein to moisture content determine the structural changing of a cheese (LAWRENCE et al., 1987).

Although protein, fat and water constitute by far the greatest part of any cheese mass, other constituents can not be ignored either. Salt in the examined Trappist cheese is not present in quantities large enough to make any sensible contribution to the rheological properties of the cheese. All of the salt is present only in solution in the water. Its effect on the properties of the whole cheese is minimal. Salt may have some 
serious contribution to the rheological properties of the cheese by indirect action. Being present at a high concentration, it inhibits the proteolysis in cheese.

Some cheeses, like Trappist, also contain a significant quantity of gas, which is concentrated in the holes. Hidden cracks or holes give rise to irregularities when measurements are made by any type of penetrometer.

The application of rheology to cheese is of the same age as rheology itself. Empirical, imitative and fundamental tests were applied alike for measuring the texture of cheese. The development of methodology was reviewed by KONSTANCE and HOLSINGER (1992). Among the empirical and imitative tests the Ball Compressor as a mechanical thumb provided some information about the mechanical deformation of the surface of the cheese (VOISEY, 1971). Among the force-measuring instruments the different kinds of penetration tests had importance because of their simplicity. A good example is the penetrometer, which uses needle as a probe. The major disadvantage of these tests was the influence of local variations and the need of multiple measurements to obtain a representative average value due to the inhomogeneity of cheese. Other types of penetration tests are the puncture tests. The punch, which is cylindrical in shape, penetrates into the food, and the instrument measures the force required to push it, and plots a force-time or force-distance curve such as the imitative test (BOURNE, 1979). The technique of texture profile analysis (TPA) was developed with the improvement of imitative methods, which imitate the action of the human jaws. SHAMA and SHERMAN (1973a, b) applied this technique (TPA) first to cheese. In the fundamental tests a given stress is applied for a given time to a sample and the relative deformation caused is observed (PRENTICE, 1984a). The deformation was measured with force-compression tests (CASIRAGHI et al., 1985; TUNICK et al., 1991; YUN et al., 1994), with creeprecovery tests or stress relaxation tests (ShAma \& ShERMAn, 1973b; Peleg, 1979; NOLAN, 1987; YUN et al., 1994). The dynamic mechanical properties were investigated with small-amplitude oscillatory shear (NOLAN et al., 1989; TUNICK et al., 1990). Although the literature on the rheological analysis of cheese is abundant, no standardised testing methods have been developed as yet; and it is also difficult to obtain representative samples. The number of the investigated cheese varieties is limited.

\section{Materials and methods}

\subsection{Cheese samples}

Trappist cheese samples were purchased from the Szekszárd Cheese Plant of the Tolna Dairy Company. All crude samples were in the original form with respect to package and weight (approx. $1 \mathrm{~kg}$ ). The crude samples were ripened at $7{ }^{\circ} \mathrm{C}$ according 
to the parameters given by the factory. The required temperature was ensured in a thermostat. One sample was examined every week in the ripening procedure and then during storage, so that the changes that occur during these periods could be revealed. The ripening procedure of the Trappist cheese was conventionally three-four weeks. The age of tested samples in the ripening procedure and then during storage was 3, 7, 14, 21 days and 28, 42, 56, 70 days, respectively. Forty samples were taken from 5 different production lots. (The samples were manufactured twice a month from February to April.)

\subsection{Qualification methods of cheese samples}

The main chemical components of the samples - dry matter, fat content in dry matter and salt content - were determined according to the HUNGARIAN STANDARDs (1989a,b,c), the protein content determination was made by Kjeldahl Tecator method (A.O.A.C., 1990). The HUNGARIAN STANDARDs (1989a,b,c) are analogouse to the ISO standards.

Besides the determination of the main chemical composition of the samples (water, fat, protein, and salt), the quantitative descriptive test of the HUNGARIAN STANDARD (1987b) (20 scores, with weighted factors) was applied during storage (21, $28,42,56,70$ days) of the cheese. The standard sensory test evaluates five characteristic groups of properties: appearance (shape), interior (colour, structure and hole formation), consistency, smell and taste, with maximum scores of 5. The sensory analysis of the cheeses was performed by a permanent panel of five panellists. They were trained, and the sensory suitability tests were carried out in accordance with the recommendations of Molnár (1991b) and Hungarian STANDARDs (1982a,b,c,d), identification of basic tastes: MSZ 7304/1, discrimination of taste: MSZ 7304/1, olfactory-test: MSZ 7304/10, and colour test: MSZ 7304/12.

The results of the sensory evaluation of ripened samples done by the panellists of the dairy company were also sent to us.

\subsection{Determination of texture parameters}

In recent years multifunctional texture test instruments have been developed which are easy to use and suitable for both imitative and empirical tests. Such an equipment is the QTS 25 Texture Analyser System (CNS Farnell, England), which evaluates the measured values with the software of Texture Profile Analysis (TPA).

The puncture test consists of measuring the force required to push a probe or punch into the food to a depth that causes irreversible crushing or flow of the food. 
The puncture test is characterised by the shape of the probe (its area and perimeter) and the depth of penetration, which is usually held constant. The rate of strain is constant if the probe is driven into the sample at a constant speed.

The interaction between the probe and the sample is complicated. At least four factors have to be taken into consideration, the compression that is applied by the face of the punch to the area under the punch, the shear that is caused by the perimeter of the punch and the edge of the sample, the frictional resistance between the surface of the probe and the cheese; and the force required to create a lateral flow within the sample.

The puncture test is made with a small flat-faced cylinder two times in a reciprocating motion which imitates the action of the jaw. The first cycle is the "first bite", the second one is the "second bite". The constant speed of the probe leads to both force-time and force-distance curves. The curves as analogues of TPA were evaluated with the software of TPA (Fig. 1).

1.3.1. Testing conditions. When decision is made on the operating conditions, the sample should be large enough to be representative of the whole (PELEG, 1977) but it must not contain hidden cracks or irregularities.

Block shaped pieces from the inside of the cheese were analysed, the surface was $14 \times 7 \mathrm{~cm}$ and the height was $4 \mathrm{~cm}$. Chewing was imitated with penetration and was carried out twice. The investigation was made on two parts of the sample, on one surface the depth of penetration was $4.00 \mathrm{~mm}$, on the other one it was $7.00 \mathrm{~mm}$. The parameters of test are in the Table 1.

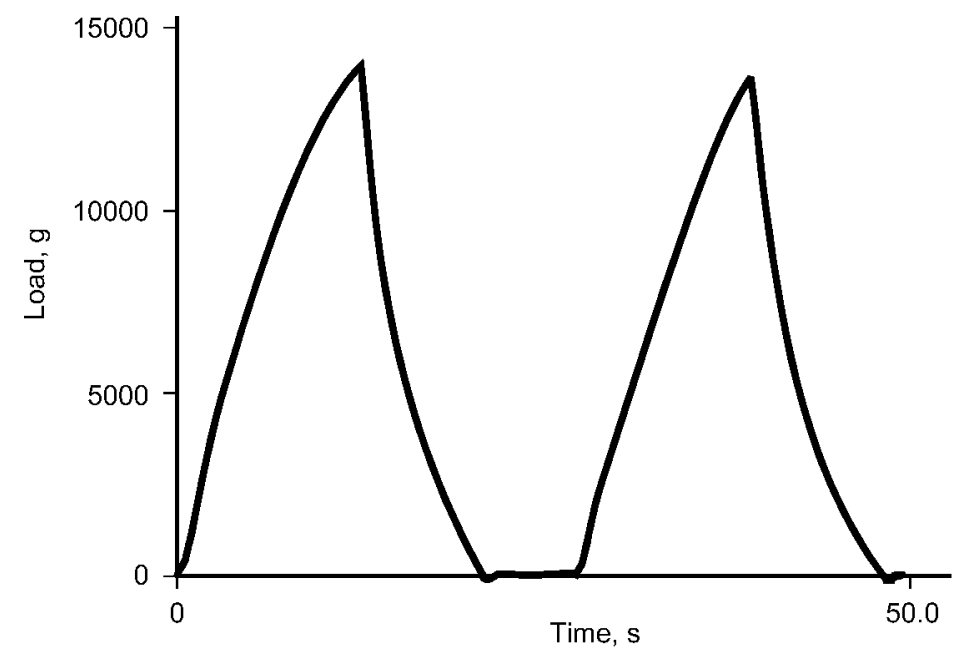

Fig. 1. TPA force-time curve of Trappist cheese 
Table 1

Parameters of test

$\begin{array}{ll}\text { Probe: } & 1.2 \mathrm{~cm} \varnothing \text { plastic cylinder } \\ \text { Type of test: } & \text { TPA } \\ \text { Speed of the probe: } & 30 \mathrm{~mm} \mathrm{~min}^{-1} \\ \text { Trigger: } & 5.0 \mathrm{~g} \\ \text { Depth of penetration } & \mathrm{a}: \\ \text { Number of cycles: } & 4.00 \mathrm{~mm} \text { or } 7.00 \mathrm{~mm} \\ \text { Sample temperature: } & 20-22{ }^{\circ} \mathrm{C} \\ \text { Number of analyses: } & \text { Each sample was analysed } 10 \text { times on different parts of the surface. } \\ & \text { At evaluation only the average of the replicates was taken into consideration. }\end{array}$

a The determination of parameters with $4.00 \mathrm{~mm}$ depth of penetration was named $1 \mathrm{st}$ mode of operation, and the determination of parameters with $7.00 \mathrm{~mm}$ depth of penetration was named $2 \mathrm{nd}$ mode of operation.

1.3.2. Mechanical parameters investigated. The next 22 parameters (Hardness $(1,2)$; Cohesiveness, Gumminess, Chewiness, Chewiness index, Modulus, Adhesive force, Adhesiveness, Springiness, Springiness index, Area (1,2); Stringiness length, Stringiness work done, Work done to hardness $(1,2)$; Recoverable deformation $(1,2)$; Recoverable work done $(1,2)$; First peak) were determined by texture analysis with ten replicate measurements. From the 22 parameters 13 primary qualities and derived parameters by importance of parameter and reliability of measurements were selected.

Primary qualities: Hardness $(1,2)$, Gumminess, Chewiness, Chewiness index, Modulus, Area $(1,2)$.

Secondary (derived) parameters: Stringiness length, Work done to hardness (2), Recoverable deformation (1,2); Recoverable work done (1). Table 2 .

The interpretation of the primary and secondary parameters can be seen in

\subsection{Mathematical statistical evaluation of data}

Sensory scores were evaluated after determination of the average scores and the rejection of outlying data in accordance with the HUNGARIAN STANDARD (1987a) "Sensory analysis of milk and dairy products" (MOLNÁR, 1991a). Data from the sensory tests and instrumental texture profile analyses (TPA) were evaluated using statistical methods (analysis of variance, principal component analysis, principal component regression and regression analysis) with the help of Statgraphics 5.0. (SVÁB, 1979).

Principal component analysis (PCA) is a multivariable method that helps to study and visualise the total structure of relationships and helps to express different characters by a few artificial variables calculated from their actual correlation (SVÁB, 1979). 
Table 2

Explanation of the measured and evaluated texture parameters

\begin{tabular}{ll}
\hline Primary results & \\
\hline $\begin{array}{l}\text { Hardness }(1 \text { \& 2) } \\
\text { Gumminess }\end{array}$ & $\begin{array}{l}\text { Maximum load during compression Cycle } 1 \text { or } 2 \\
\text { Hardness (Cycle 1) multiplied by the ratio of the positive force area } \\
\text { in the second compression and that of the first compression } \\
\text { Gumminess multiplied by the distance the beam travels when } \\
\text { compressing the sample in cycle } 2\end{array}$ \\
Gumminess & $\begin{array}{l}\text { compressing the sample in cycle } 2 \text { divided by target distance value } \\
\text { Gradient of curve between } 20 \text { and } 80 \% \text { of Hardness (Cycle } 1)\end{array}$ \\
Thewiness index & Total positive area in cycle 1 or 2
\end{tabular}

\section{Results}

\subsection{Qualification of samples on the basis of chemical composition and sensory tests}

The quality of ripened cheese samples was "appropriate" according to the HUNGARIAN STANDARD (1987b). It was based on the chemical composition and the weighted scores of sensory tests. The products had "excellent" quality (average weighted scores of sensory tests were 17.85 in the Dairy Company and 18.06 was given by our panellists). Tables $3 \mathrm{a}$ ) and $3 \mathrm{~b}$ ) show the chemical composition of the samples and the results of sensory tests that aimed to determine shelf-life.

\subsection{Selecting the textural parameters}

Out of the 22 rheological parameters determined, 13 directly measured values or derived data were selected which were determined as reproducible (average variation coefficient is smaller than 40\%) (COCK, 1994) and which correlated significantly $(\mathrm{P}<0.05)$ with the age of product in the case of both modes of operation. 
Table 3a

Major chemical components of Trappist cheese samples

\begin{tabular}{|c|c|c|c|c|}
\hline \multirow[b]{2}{*}{ Manufacturing } & \multicolumn{4}{|c|}{ Constituent } \\
\hline & $\begin{array}{l}\text { Dry material } \\
\mathrm{g} / 100 \mathrm{~g}\end{array}$ & $\begin{array}{c}\text { Fat content } \\
\text { in dry material } \\
\mathrm{g} / 100 \mathrm{~g}\end{array}$ & $\begin{array}{l}\text { Salt content } \\
\mathrm{g} / 100 \mathrm{~g}\end{array}$ & $\begin{array}{c}\text { Protein content } \\
\mathrm{g} / 100 \mathrm{~g}\end{array}$ \\
\hline I & 57.46 & 45.25 & 1.71 & 24.90 \\
\hline II & 58.06 & 46.50 & 1.55 & 23.14 \\
\hline III & 59.32 & 46.36 & 1.60 & 24.85 \\
\hline IV & 57.46 & 45.25 & 1.81 & 19.89 \\
\hline V & 57.75 & 45.83 & 1.68 & 21.74 \\
\hline Acceptance range & $58.0 \pm 2.5$ & $45.0 \pm 2.0$ & $1.5 \pm 0.5$ & \\
\hline
\end{tabular}

$\mathrm{n}=8$ samples per manufacturing

Table $3 b$

Results of sensory tests

\begin{tabular}{lcccccc}
\hline Manufacturing & \multicolumn{5}{c}{ Weighted total scores } \\
\cline { 2 - 6 } Age (days) & 21 & 28 & 42 & 56 & 70 & $\begin{array}{c}\text { Data from the } \\
\text { Company } \\
\text { (21 days) }\end{array}$ \\
\hline I & & & & & 16.9 & 18.04 \\
II & 17.9 & 18.8 & 19.3 & 16.6 & 16.8 & 18.2 \\
III & 18.6 & 18.4 & 17.6 & 16.4 & 18.4 & 17.2 \\
IV & - & 18.6 & 19.0 & 19.2 & 12.3 & 18.0 \\
V & 17.1 & 16.9 & 16.3 & 14.2 & 14.4 & 17.8 \\
\hline Average & 17.2 & 17.6 & 16.8 & 14.7 & 15.76 & $\mathbf{1 7 . 8 5}$ \\
\hline
\end{tabular}

$\mathrm{n}=5$ samples from different production lots

The average value of the test results of 40 products, 10 measurements per product, the average values of the variation coefficient of replicate measurements (10), the correlation coefficients between the age of the product and each texture parameter are shown in Table 4. Most of the selected parameters (Hardness (1,2), Gumminess, Chewiness, Chewiness index, Modulus, Area (1,2), Work done to hardness (2), Recoverable deformation $(1,2)$; Recoverable work done (1)) are negatively correlated with the age of product. They show a downward tendency as a function of time. 
Table 4

Measurement of textural parameters and the correlation between the age of cheese and the parameters

\begin{tabular}{|c|c|c|c|c|c|c|}
\hline \multirow{2}{*}{$\begin{array}{c}\text { Textural parameters (Units) } \\
\text { depth of penetration: }\end{array}$} & \multirow{2}{*}{$\begin{array}{r}\begin{array}{c}\text { Average } \\
\text { value }\end{array} \\
4\end{array}$} & \multirow{2}{*}{$\begin{array}{l}\mathrm{VC}^{\mathrm{a}} \\
(\%) \\
m\end{array}$} & \multirow{2}{*}{$\begin{array}{c}\begin{array}{c}\text { Average } \\
\text { value }\end{array} \\
7\end{array}$} & \multirow{2}{*}{$\begin{array}{l}\mathrm{VC}^{\mathrm{a}} \\
(\%) \\
n\end{array}$} & \multicolumn{2}{|c|}{$\begin{array}{l}\text { The values of } \\
\text { correlation coefficients } \\
\text { between age of product and } \\
\text { each textural parameter }\end{array}$} \\
\hline & & & & & $4 \mathrm{~mm}$ & $7 \mathrm{~mm}$ \\
\hline Hardness1 (g) & 2969 & 16 & 6031 & 10 & $-0.4308 * *$ & $-0.3299 *$ \\
\hline Hardness2 (g) & 3139 & 16 & 6224 & 10 & $-0.4502 * *$ & $-0.3807 *$ \\
\hline Cohesiveness (none) & 1.08 & 2 & 0.999 & 4 & -0.2874 & $-\mathbf{0 . 6 2 9 7} * * *$ \\
\hline Gumminess (g) & 3190 & 15 & 6025 & 11 & $-0.4683 * *$ & $-0.4329 * *$ \\
\hline Chewiness $(\mathrm{g} \times \mathbf{m m})$ & 10872 & 17 & 35573 & 11 & $-0.4707 * *$ & $-0.4064 * *$ \\
\hline Chewiness index (none) & 2719 & 17 & 5082 & 11 & $-0.4708 * *$ & $-0.4064 * *$ \\
\hline Modulus (none) & 305 & 16 & 360 & 10 & $-0.4027 * *$ & $-0.3103^{*}$ \\
\hline Adhesive force (g) & 112 & 40 & 393 & 43 & $0.5627 * * *$ & $0.6460 * * *$ \\
\hline Adhesiveness $(\mathrm{g} \times \mathrm{mm})$ & 137 & 52 & 726 & 70 & $0.6961 * * *$ & $0.6804 * * *$ \\
\hline Springiness $(\mathrm{mm})$ & 3.33 & 2 & 5.89 & 2 & $-0.3280 *$ & 0.1238 \\
\hline Springiness index (none) & 0.83 & 2 & 0.84 & 2 & -0.2805 & 0.1938 \\
\hline Area $1(\mathbf{g} \times \mathbf{s})$ & 23652 & 18 & 82488 & 11 & $-0.4149 * *$ & $-0.3247 *$ \\
\hline Area $2(\mathrm{~g} \times \mathbf{s})$ & 25396 & 17 & 82372 & 11 & $-0.4536 * *$ & $-0.4294 * *$ \\
\hline Stringiness length (mm) & 0.41 & 23 & 0.79 & 31 & $0.6612 * * *$ & $0.7321 * * *$ \\
\hline Stringiness work done $(\mathrm{g} \times \mathrm{s})$ & 65 & 51 & 582 & 72 & $0.6292 * * *$ & $0.6653 * * *$ \\
\hline Work done to hardness $1(\mathrm{~g} \times \mathrm{s})$ & 16280 & 18 & 59506 & 11 & $-0.3907 *$ & -0.2862 \\
\hline Work done to hardness $2(\mathrm{~g} \times \mathrm{s})$ & 17205 & 16 & 58157 & 11 & $-0.4366^{* *}$ & $-0.3995^{*}$ \\
\hline Recoverable deformation 1 (mm) & 2.49 & 4 & 4.37 & 2 & $-0.6449 * * *$ & $-0.7269 * * *$ \\
\hline Recoverable deformation 2 (mm) & 2.67 & 4 & 4.57 & 3 & $-0.6404 * * *$ & $-\mathbf{0 . 7 7 0 5} * * *$ \\
\hline Recoverable work done $1(\mathrm{~g} \times \mathrm{s})$ & 7367 & 19 & 22955 & 12 & $-0.4557 * *$ & $-0.4071 * *$ \\
\hline Recoverable work done $2(\mathrm{~g} \times \mathrm{s})$ & 8190 & 19 & 24212 & 12 & 0.1765 & 0.0662 \\
\hline First peak (g.) & 25 & 60 & 39 & 43 & $0.3280 *$ & $0.3355^{*}$ \\
\hline
\end{tabular}

${ }^{a}$ Variation coefficient (VC): average values of variation coefficient of replicate measurements $* \mathrm{P}<0.05, * * \mathrm{P}<0.01, * * * \mathrm{P}<0.001$

The definitions of Units are not common. These were defined by the Company. The software of the QTS25 uses ones. The work type Units have to take the speed of the probe into account to get correct Units.

\subsection{Evaluation of textural parameters with principal component analysis}

Principal component analysis (PCA) was carried out on 13 variables of all samples. It was found that on the basis of the correlation of the original variables, variables could be reduced to one single and two principal component variables in the 
case of the two modes of operation. The eigenvalue of the factors and the cumulative percentage $\left(\mathrm{h}^{2}\right)$ are shown in Table 5. The first principal component covers more than $87 \%$ of the variance of the original variables determined with both modes of operation. The importance of the first principal component is expressed by the high eigenvalue (JACKMAN \& YADA, 1989).

From the values of principal component weights the relative importance of the original variables can be seen compared to each of the respective principal components.

The first principal component is determined by 10 variables to an approximately equal extent in both cases (Hardness1,2; Guminess; Chewiness; Chewiness index; Modulus; Area 1,2; Work done to hardness 2; Recoverable work done 1).

The second principal component is determined by three variables (Stringiness length and Recoverable deformation $(1,2))$ in the case of the 2 nd. mode of operation.

Table 5

Results of principal component analysis $(n=40, p=13)$

\begin{tabular}{cccccrrr}
\hline & \multicolumn{3}{c}{ 1st mode of operation } & \multicolumn{5}{c}{ 2nd mode of operation } \\
\hline No. of PC & $\lambda$ & variance $\%$ & $\mathrm{~h}^{2}$ & No. of PC & $\lambda$ & variance \% & $\mathrm{h}^{2}$ \\
\hline \multirow{2}{*}{1} & 11.83 & 91.03 & $\mathbf{9 1 . 0 3}$ & 1 & 11.35 & 87.29 & 87.29 \\
& & & & 2 & 1.30 & 9.99 & $\mathbf{9 7 . 2 8}$ \\
\hline
\end{tabular}

\subsection{Comparison of samples from various manufacturing time on the basis of values of first few principal components}

Samples from different manufacturing time were compared with analysis of variance to show whether there were significant differences between the manufacturing processes on the basis of the first principal components that were determined with various modes of operation (4 and $7 \mathrm{~mm}$ penetration). The analysis of variance of the first few principal components carried out with different modes of operation can be found in Fig. 2.

If the subgroups of the different manufacturing processes are compared, it can be concluded in the case of both modes of operation that the average values of the first three manufacturing lots were greater than those of the last two, but there are no significant differences between them. 
a

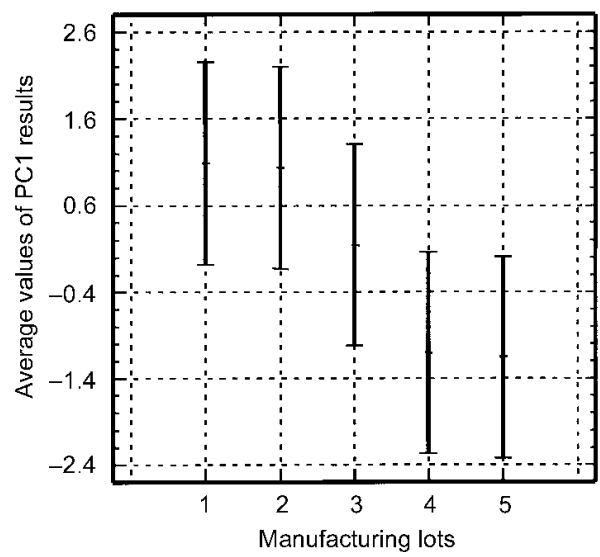

95 Percent Confidence Intervals

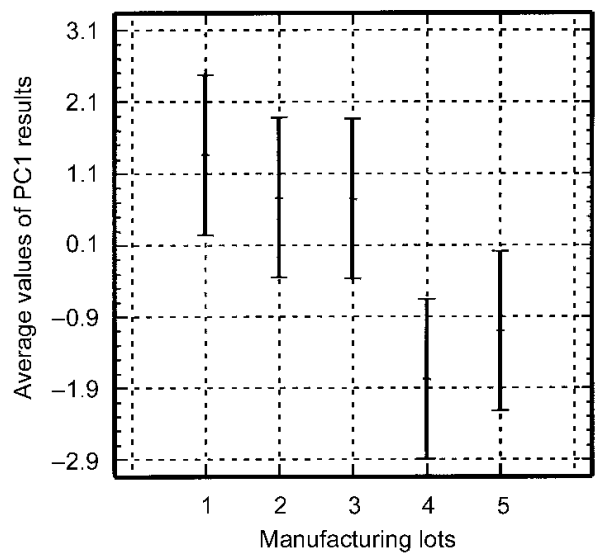

Fig. 2. Analysis of variance of textural parameters, carried out with two modes of operation. a: $4 \mathrm{~mm}$ penetration depth; b: $7 \mathrm{~mm}$ penetration depth

\subsection{Estimation of the product age}

The textural properties depended on the composition of crude cheese and the extent of ripeness. The developments of textural properties during ripening and subsequent storage of cheese were different, therefore, it is reasonable to take all properties into the evaluation of time dependence.

2.5.1. Estimation with principal component regression. The age of the product (i.e. period of time that has elapsed since the product was manufactured; actually the sum of ripening time and storage time) can be estimated from the principal components with principal component regression according to the $\mathrm{y}=\mathrm{a}_{1} \mathrm{x}_{1}+\mathrm{a}_{2} \mathrm{x}_{2}+\ldots+\mathrm{a}_{\mathrm{n}} \mathrm{x}_{\mathrm{n}}+\mathrm{b}$ equation, where $\mathrm{y}$ is the age of the product (days) and $\mathrm{x}_{1}, \mathrm{x}_{2}, \ldots \mathrm{x}_{\mathrm{n}}$ are the principal components. When all principal components (13) were used in the formula, the age of the product could be estimated with 12 days accuracy. (Standard errors of estimates at both modes of operation are $12.02(\mathrm{a}=4.00 \mathrm{~mm}$ depth of penetration) and $11.85(\mathrm{~b}=7.00 \mathrm{~mm}$ depth of penetration), $\left.r_{a}=0.9016 ; r_{b}=0.9045\right)$. These values were compared to the full periods (ripening and storage) (70 days) that had a 17\% accuracy. These principal components 
a

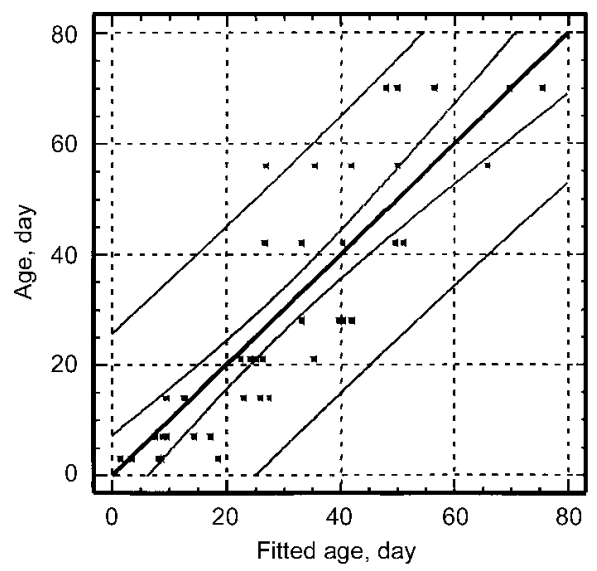

b

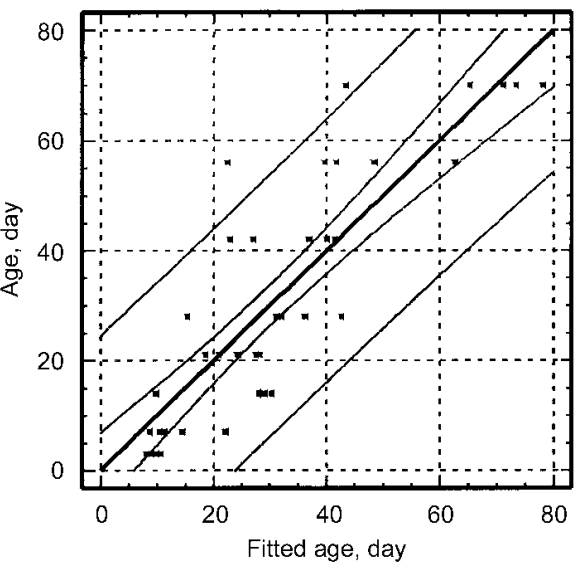

Fig. 3. Estimation of the product age by principal component regression, carried out with two modes of operation. a: $4 \mathrm{~mm}$ penetration depth; b: $7 \mathrm{~mm}$ penetration depth; Y: age of the cheese, PCX-Xth Principal component SE: standard error. a) $\mathrm{Y}=-3.35 \times \mathrm{PC} 1-14.92 \times \mathrm{PC} 2+9.36 \times \mathrm{PC} 3-102.59 \times \mathrm{PC} 7+$ $1201.60 \times \mathrm{PC} 12+30.12 \mathrm{SE}=12.88 \mathrm{R}=0.848 \mathrm{n}=40 \mathrm{P}<0.001 ; \mathrm{b}) \mathrm{Y}=-3.21 \times \mathrm{PC} 2+49.02 \times \mathrm{PC} 6-$ $112.66 \times \mathrm{PC} 9+30.12 \mathrm{SE}=12.12 \mathrm{R}=0.863 \mathrm{n}=40 \mathrm{P}<0.001$

were selected by stepwise variable selection that estimated the age with the same significance. At the $5 \mathrm{~mm}$ depth of penetration the age of the product could be estimated with five (PC1, PC2, PC3, PC7, PC12) and at the $7 \mathrm{~mm}$ depth of penetration with four (PC1, PC2, PC6, PC9) principal components. The equations between the observed and fitted values of age are on the Fig. 3.

At the $7 \mathrm{~mm}$ depth of penetration the number of principal components were less and inaccuracy in estimation was better than at the $4 \mathrm{~mm}$ depth of penetration. The first principal component occurred in both formulas with negative coefficient.

2.5.2. Estimation with original variables. The age of the product was estimated with stepwise variable selection and multiple regression analyse involving all the original variables because in the first two principal components all the 13 variables occurred significantly. The standard equation of the estimating formula: $\mathrm{y}=\mathrm{a}_{1} \mathrm{x}_{1}+\mathrm{a}_{2} \mathrm{x}_{2}+\ldots+\mathrm{a}_{\mathrm{n}} \mathrm{x}_{\mathrm{n}}$, where $\mathrm{y}=$ age of the product, $\mathrm{x}_{1}, \mathrm{x}_{2}, \ldots \mathrm{x}_{\mathrm{n}}=$ texture parameters. The equations between the observed and fitted values of age are on Fig. 4. 

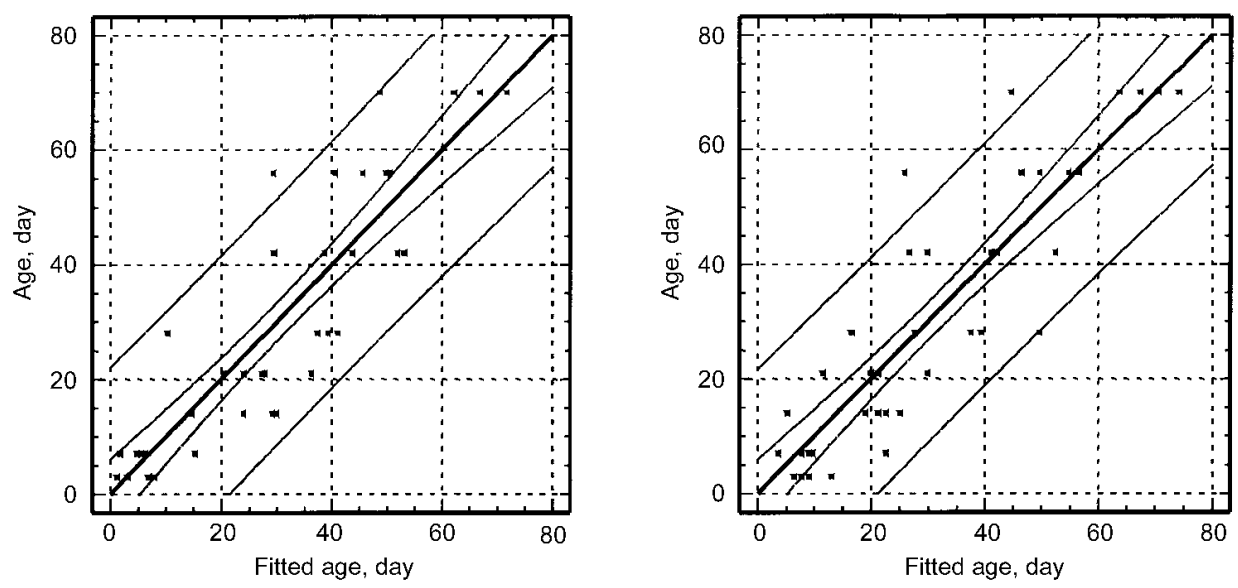

Fig. 4. Estimation of the product age by original parameters, carried out with two modes of operation. a: $4 \mathrm{~mm}$ penetration depth, b: $7 \mathrm{~mm}$ penetration depth, $\mathrm{Y}$ : age of the cheese, $\mathrm{x}$ : textural parameter SE: standard error. a) $\mathrm{Y}=-1.102 \mathrm{x}_{1}+1.026 \mathrm{x}_{2}+0.525 \mathrm{x}_{3}+0.162 \mathrm{x}_{4}-0.122 \mathrm{X}_{5}+107.954 \mathrm{x}_{6}-0.0247 \mathrm{X}_{7}-16.45 \mathrm{x}_{8}-$ $\left.0.0602 \mathrm{x}_{9} \mathrm{SE}=11.59 \mathrm{R}=0.962 \mathrm{n}=40 ; \mathrm{b}\right) \mathrm{Y}=0.112 \mathrm{x}_{1}-0.0164 \mathrm{x}_{2}-0.0117 \mathrm{x}_{3}+28.192 \mathrm{x}_{4}$ $+0.0119 x_{5}+56.247 x_{6}-59.808 x_{7}+0.00938 x_{8} S E=11.23 R=0.963 n=40$

At the $4 \mathrm{~mm}$ depth of penetration product age could be estimated from 9 variables (Hardness (1), Gumminess, Modulus, Area $(1,2)$, Stringiness length, Work done to hardness (2), Recoverable deformation (1), Recoverable work done (1); and at the $7 \mathrm{~mm}$ penetration with 8 variables (Gumminess, Chewiness, Stringiness length, Work done to hardness (2), Recoverable deformation (1,2); Recoverable work done (1) with near the same accuracy. The estimation inaccuracy at the $7 \mathrm{~mm}$ depth of penetration was better to a minimum extent, e.g. 11.2 days, which was of $16 \%$ accuracy related to the whole period.

\subsection{Relationships between sensory tests and textural parameters}

A correlation was tried to be established between sensory test based on product standards and textural parameters measured with instrument, in order to establish whether it is possible to draw definite conclusions from the changes in textural parameters and the quality of sensory test.

Textural parameters were selected with stepwise variable selection to which the total sensory score correlated. The total sensory score at the $4 \mathrm{~mm}$ depth of penetration could be estimated with 1.205 point accuracy from the value of stringiness length according to the equation of $\mathrm{Y}=-13.735 \times$ Stringiness length +21.534 equation 
$(\mathrm{R}=0.804, \mathrm{SE}=1.205, \mathrm{n}=24, \mathrm{P}<0.001)$. At the $7 \mathrm{~mm}$ depth of penetration the estimation formula of the total sensory score $\mathrm{Y}=0.000522 \times$ Gumminess $-1.393 \times$ Stringiness length $+15.368(\mathrm{R}=0.802, \mathrm{SE}=1.24, \mathrm{n}=24, \mathrm{P}<0.001)$. Both parameters related to the sample behaviour were observed during sensory test of the samples. The Stringiness length is connected with the rate of which a deformed sample goes back to its undeformed condition after the deforming force is seized. Gumminess is the quantity to simulate the energy required to disintegrate a semi-solid sample to a steady state of swallowing.

Since the total sensory score changes over the course of time according to the maximum curve while the textural parameters have a straight line correlation, the established relations are valid only after the optimal ripening condition, that is for the second part of shelf-life.

\section{Conclusions}

The changes in texture of Trappist samples from five different manufacturing processes during ripening time and storage were characterised by remarkable changes in various texture parameters. The ripened samples were of "excellent" quality according to the compositional analyses and sensory tests. There was a significant difference in the mechanical parameters for the first three and last two manufacturing processes. The following conclusions can be drawn from the results of our investigations, despite the inhomogeneity of samples, which was due to the manufacturing processes.

- The 13 chosen mechanical parameters revealed a close correlation. Because of this it was also possible to have a description with just one or two variables. On the basis of principal component weights, it was established from the two methods of measurement that the first main component was basically determined by 10 of the original characteristics, while the second main component was determined by the remaining 3 .

- Between the values of principal components and the age of cheese a multiple linear correlation was observed. The values of principal components differred at the 4 and $7 \mathrm{~mm}$ depths of penetration, so the age of the product could be estimated with the use of a varied number of principal components $(5,4)$.

- Selecting those original variants, which had multiple linear correlation with the age of products an estimation formula was developed. Using this formula the age of cheese could be estimated using 9 variables at the $4 \mathrm{~mm}$ depth of penetration and 8 variables at the $7 \mathrm{~mm}$ depth of penetration with 11 days of accuracy.

- A correlation was found between the total sensory score indicating product quality and texture parameters related to the sensory test of samples (gumminess, chewiness) in the second section of shelf-life (after 42 days) in a way that the sensory score could be estimated from texture parameters with an accuracy of 1.20-1.24 score points. 
- According to the data and processed data obtained from using the two measurement techniques, it can be said that, despite that both methods showed a correlation between product age and sensory score at a similar significance level and at a $7 \mathrm{~mm}$ penetration depth, but the number of variables used to estimate the time being less, so the accuracy of this estimation formula was better. Based on these results it is suggested that the $7 \mathrm{~mm}$ penetration depth be used for further tests on samples of Trappist cheese.

\section{References}

Bourne, M. C. (1979): Theory and application of the puncture test in food texture measurement. -in: Sherman, P. (Ed.) Food texture and rheology. Academic Press, London, pp. 95-142.

Casiraghi, E. M., Barley, E. B. \& Christianson, D. D. (1985): Behaviour of Mozzarella, Cheddar and processed cheese spread in lubricated and bonded uniaxial compression. J. Texture Stud., 16, 281-301.

Cock, P. (1994): Starch compositions for texture-design of pasta cocktail snacks. Food Ingredients Europe'94 Conference proceedings. pp. 101-105.

CODEX AlimenTARIUS Hungaricus (1995): Trappista sajt. (Trappist cheese.) MÉ 2-51/09/12-1.2.

Creamer, L. K. \& Olson, N. F. (1982): Rheological evaluation of maturing Cheddar cheese. J. Fd. Sci., 47 , 631-636, 646.

FARKYE, N. Y. \& FoX, P. F. (1990): Objective indices of cheese ripening. Trends Fd. Sci. Technol., 1, 37-40.

Fox, F. \& Mulvihill, D. M. (1990): Casein. -in: Harris, P. (Ed.) Food gels. Elsevier Science Publishers, London, pp. 121-173.

HUNGARIAN STANDARD (1982a): Élelmiszerek érzékszervi vizsgálati módszerei: A szaglóképesség vizsgálata. (Sensory test methods of foodstuffs: Examination of sense of smell.) MSZ 7304/10-82.

Hungarian STANDARD (1982b): Élelmiszerek érzékszervi vizsgálati módszerei: Színmegállapító képesség vizsgálata. (Sensory test methods of foodstuffs: Examination of sense of coloured vision.) MSZ 7304/12-82.

HUNGARIAN STANDARD (1982c): Élelmiszerek érzékszervi vizsgálati módszerei: Ízkülönbség vizsgálata. (Sensory test methods of foodstuffs: Tests of tastes.) MSZ 7304/1-82.

HUNGARIAN STANDARD (1982d): Élelmiszerek érzékszervi vizsgálati módszerei: Ílelõképesség vizsgálata. (Sensory test methods of foodstuffs: Examination of sense of tasting.) MSZ 7304/1-82.

Hungarian StANDARD (1987a): Tej és tejtermékek érzékszervi elemzõ vizsgálata. (Sensory Analysis of Milk and Dairy Products.) MSZ 12292-87.

Hungarian STANDARD (1987b): Trappista sajt. (Trappist cheese.) MSZ 12280-87.

Hungarian STANDARD (1989a): Sajt, ömlesztett sajt és túró kémiai és fizikai vizsgálata. A zsírtartalom meghatározása. (Chemical and physical test for cheese, processed cheese and quark. Determination of fat content.) MSZ 2714/1-1989 = ISO 3433-1975.

Hungarian StANDARD (1989b): Sajt, ömlesztett sajt és túró kémiai és fizikai vizsgálata. A víz-, illetve a szárazanyag-tartalom meghatározása. (Chemical and physical test for cheese, processed cheese and quark. Determination of water and solid content.) MSZ 2714/2-1989 = ISO 5534-1985.

Hungarian STANDARD (1989c): Sajt, ömlesztett sajt és túró kémiai és fizikai vizsgálata. Nátrium-kloridtartalom meghatározása. (Chemical and physical test for cheese, processed cheese and quark. Determination of salt content.) MSZ 2714/3-1989 = ISO 2970-1974. 
JACKMAN, R. L. \& YADA, R. Y. (1989): Multivariate analysis of functional and structure-related properties of whey-vegetable protein composites. Can. Inst. Fd. Sci. Technol. J., 22, 260-269.

Kliermeier, F. \& LeChner, E. (1973): Milch und Milcherzeugnisse. Verlag Paul Parey, Berlin und Hamburg, p. 161.

Konstance, R. P. \& Holsinger, V. H. (1992): Development of rheological test methods for cheese. Fd. Technol., 46, 105-109.

Lawrence, R. C., Creamer, L. K. \& Gilles, J. (1987): Texture development during cheese ripening. J. Dairy Sci., 70, 1748-1760.

MolnáR, P. (1991a): Élelmiszerek érzékszervi vizsgálata. (Sensory analysis of food.) Akadémiai Kiadó, Budapest, pp. 171-173.

MoLNÁR, P. (1991b): Az élelmiszerminõség meghatározásának újabb szempontjai. (New aspects to establish food quality.) Élelmezési Ipar, 42, 379-383.

Nolan, E. J. (1987): Stress relaxation of stored stirred cheddar curd. J. Texture Stud., 18, 273-280.

Nolan, E. J., Holsinger, V. H. \& SHIEH, J. J. (1989): Dynamic rheological properties of natural and imitation Mozzarella cheese. J. Texture Stud., 20, 179-183.

A.O.A.C. (1990): Determination of total nitrogen in cheese. Official Methods of Analysis, AOAC 955.30.

PELEG, M. (1977): The role of the specimen dimensions in uniaxial compression of food materials. $J$. Fd Sci., 42, 649-651.

PELEG, M. (1979): Characterisation of the stress relaxation curves of solid foods. J. Fd Sci., 44, 277-281.

PRENTICE, J. H. (1984a): Measurements in the rheology of foodstuffs. Elsevier Science Publishers, London, pp. 5-19.

PRENTICE, J. H. (1984b): Measurements in the rheology of foodstuffs. Elsevier Science Publishers, London, pp. 153-163.

Shama, F. \& ShERman, P. (1973a): Evaluation of some textural properties of foods with the Instron Universal Testing Machine. J. Texture Stud., 4, 344-352.

Shama, F. \& Sherman, P. (1973b): Stress relaxation during force compression studies on foods with the Instron Universal Testing Machine and its implications. J. Texture Stud., 4, 353-362.

SvÁB, J. (1979): Többváltozós módszerek a biometriában. (Multivariable methods in biometrics.) Mezõgazdasági Kiadó, Budapest, pp. 33-68.

Tunick, M. H., Mackey, K. L., Smith, P. W. \& Holsinger, V. H. (1991): Effect of composition and storage on the texture of Mozzarella cheese. Netherlands Milk Dairy J., 45, 117-125.

Tunick, M. H., Nolan, E. J., Shieh, J. J., Basch, J. J., Thompson, M. P., Maleeff, B. E. \& Holsinger, V. H. (1990): Cheddar and Cheshire cheese rheology. J. Dairy Sci., 73, 1671-1675.

Yun, J. J., Hsieh, L. Y., Barbano, M. D. \& Kindstedt, S. P. (1994): Draw pH and storage affect rheological properties of Mozzarella cheese. J. Fd. Sci., 59, 1302-1304.

VOISEY, P. W. (1971): Modernisation of texture instrumentation. J. Texture Stud., 2, 129-195. 